WIELKIE TEMATY KULTURY W LITERATURACH SKOWIAŃSKICH

Slavica Wratislaviensia CLXVIII • Wrocław 2019•AUWr No 3875

DOI: 10.19195/0137-1150.168.45

Data przesłania artykułu: 13.09.2017

Data akceptacji artykułu: 6.01.2018

DIJANA HADŽIZUKIĆ

Univerzitet „Džemal Bijedić“ u Mostaru, Bośnia i Hercegowina

\title{
Motiv smrti u romanima Dževada Karahasana
}

\author{
Valja umrijeti, brate moj, znajući da nisi \\ pročitao ni deseti dio onoga \\ što si morao,ni stoti dio onoga što si \\ trebao, ni hiljaditi onoga što si želio... \\ (Dževad Karahasan, Što pepeo priča)
}

Otkako postoji književnost, bilo da se radi o usmenim ili pisanim oblicima, pitanje čovjekove smrtnosti, potraga za besmrtnošću ili promišljanje prostora onostranog nameću se kao jedna od najvažnijih tema u prozi, odnosno, motiva u poetskom izrazu. Ne postoji autor koji u svom književnoumjetničkom opusu ne dotiče temu smrti, a s obzirom na epohu u kojoj stvara ili književnu formaciju kojoj pripada, pa čak i civilizacijski krug u kojemu je kulturalno stasao, odnos umjetnika prema smrti je specifičan i upravo navedenim uvjetima određen. U tom smislu, smatramo da je važno propitati motiv smrti u romanima Dževada Karahasana ${ }^{1}$, zasigurno najvećeg živućeg bosanskohercegovačkog književnika koji u svome radu spaja Istok i Zapad, kako u pogledu formalnih književnih odlika tako i u pogledu filozofskih i religijskih promišljanja. Unutar njegovih romana intertekstualno se prepliću kriminalistički roman i adab ${ }^{2}$, epistolarna forma sa formom basne iz Hiljadu i jedne noći, kao i platonistički i neoplatonistički stavovi

${ }^{1}$ Dževad Karahasan (Duvno, 1953) školovao se u Duvnu, Sarajevu i Zagrebu. Radio je kao dramaturg u Zenici, Sarajevu i Salzburgu, predavao na univerzitetima u Sarajevu, Salzburgu, Gottingenu, Berlinu. Knjige su mu prevedene na petnaest jezika. Između ostalog, napisao je romane: Istočni diwan, Šahrijarov prsten, Sara i Serafina, Noćno vijeće, knjige pripovijedaka Kuća za umorne i Izvještaji iz tamnog vilajeta, te knjige eseja O jeziku i strahu, Dnevnik selidbe, Knjiga vrtova. Dobitnik je brojnih međunarodnih nagrada i priznanja.

${ }^{2}$ Vrsta srednjovjekovne arapske priče poučnog karaktera. 
sa kršćanskom gnozom ili islamskim sufizmom. Izvori na kojima će se zasnivati ovaj ogled jesu Karahasanovi romani Istočni diwan (1989) i Šahrijarov prsten (1994). Svjesno izostavljamo njegov roman Sara i Serafina (1991) čiji je hronotop opkoljeno i uništeno Sarajevo devedesetih godina dvadesetog vijeka jer on zahtijeva zasebnu studiju o smrti u ratnom Sarajevu, kao i posljednji roman Što pepeo priča (2015) kojim ćemo se pozabaviti u proširenom tekstu istoga naslova. S druge strane, motiv smrti u pripovijetkama Dževada Karahasana, kao i u romanu Noćno vijeće (2005) obradila je u svom sjajnom tekstu Andrijana Kos-Lajtman ${ }^{3}$, posebnu pažnju posvećujući tumačenju islamske kozmologije, prije svega Berzaha koji je u eshatologiji međuprostor a u kozmologiji međusvijet, a koji se pokazao ključnim mjestom romana Noćno vijeće. Autorica je, poredeći zapadnjački sa istočnjačkim odnosom prema smrti, analizirala pitanja čovjekove izmještenosti u kontaktu sa onostranim, prepoznala mjesta u kojima se smrt pojavljuje kao izbavljenje/smirenje/dovršenje, ukazala na mjesta u kojima se smrt pokazuje kao sestra ljubavi ili kao čin kreacije, imajući pri tome na umu da:

Čitava paradigma kršćanstva, islama, ali i drugih, ne nužno teoloških postavki (recimo, Kantova koncepcija tzv. kategoričkog imperativa) počiva na pretpostavci da se čovjek kao biće koje se zatječe u rascjepu materijalnog i duhovnog, svojim vlastitim nastojanjem uzdiže iz tjelesnog bića u duhovno - sudjelujući u 'dobroti' božanskog, i to upravo svojom slobodom da može izabrati što će biti i činiti ${ }^{4}$.

Romani Istočni diwan i Šahrijarov prsten sa strukturom priče u priči, tematizacijom pronađenog rukopisa, igrom sa različitim pripovjednim obrascima koji na kraju uvijek budu iznevjereni, historijskim hronotopom i akterima, orijentacijom na čitatelja u kojem se traži aktivan sugovornik i dovršitelj značenja, dijalogom sa tradicionalnom kulturom, te velikim citatnim dijalogom, tipični su romani postmodernizma ${ }^{5}$. U tom smislu, s jedne strane, smrt se pojavljuje kao bitan strukturalni elemenat krimi-priče ili priče sa elementima političke zavjere, dok se, s druge strane, motiv smrti duboko provlači kroz filozofsko-religijsku misao kako Karahasanovih protagonista koji su u pravilu mistici, tako i romana u cjelini.

Uobičajen ezoterički stav o ljudskoj smrti podrazumijeva doživljaj smrti koja je lijepa smrt, preobražaj, posvećenje i napredak; umire se da bi se rodilo za život na višem nivou. U romanu Istočni diwan ovakvih umiranja nema jer su gotovo sve smrti nasilne. Jedina nenasilna smrt (uvjetno) jeste Zubeidova iz umetnute priče o Mutevekilu i Zubeidu: Zubeidu su za kaznu odsjekli ruke i noge, a onda se, zbog

${ }^{3}$ A. Kos-Lajtman, Drugo lice smrti: tretman i uloga teme smrti u prozi Dževada Karahasana, „Sarajevske sveske“ 2016, br. 49-50, s. 211-226.

${ }^{4}$ Ibidem, s. 212.

${ }^{5} \mathrm{O}$ različitim vidovima postmoderne poetike u romanima Dž. Karahasana pisali su brojni autori: M. Babić, V. Preljević, S. Kodrić, Lj. Šop, E. Karić, N. Petković, M. Dželilović, J. Ahmetagić, A. Bašović, E. Kazaz, Z. Mlinarević, D. Hadžizukić, F. Kujundžić i brojni drugi, kao i A. Denić-Grabić u knjizi Otvorena knjiga: elementi postmodernog diskursa u romanima Istočni diwan i S̆ahrijarov prsten Dževada Karahasana, Sarajevo-Zagreb 2005. 
osjećaja krivnje radi izgovorenih riječi koje su realizirane, Mutevekil pretakao u Zubeida da bi, na kraju, drugi umro a prvi nestao ne razriješivši tajnu međusobnog sukoba. Pjesnik Mutevekil je izgovorio riječi o kazni za Zubeida, a ljudi iz vlasti su ih doslovno realizirali. Priču o njima je napisao Mukaffa ${ }^{6} \mathrm{u}$ jednom od pisama za Begzadu, da bi, na kraju, on završio tako što su mu odsjekli ruke i noge, spalili udove pred njim a onda ga ubili. Njegova strašna smrt na fabularnom nivou predstavlja jedno od političkih ubistava, dok je na kompozicionom i semantičkom nivou romana Mukaffina smrt, s jedne strane, dio priče o odgovornosti prema izgovorenoj ili zapisanoj riječi, a s druge strane, jedno od čvorišta romana u kojima se ogleda stradanje onoga ko je miš iz (opet njegove) poučne priče o nasumičnom lancu događaja koji vode od gladnog lava do smrti miša. Moramo pomenuti i izrazito nasilnu smrt slikara iz adaba o Gazvanu i slikaru, koju emir straže jeste uspješno riješio samo zato da bi bila dokazana njegova racionalistička metoda, ali i da bi bila ispričana priča o nestanku djevojčice-modela i njenom prelasku u paralelni svijet jer je slika bila savršena.

Savršeno naslikati ovaj, vidljivi svijet, znači pretočiti ga u neki od nevidljivih, a Bogu to nije drago jer On voli množinu svojih svjetova koji se međusobno odražavaju, sudaraju i mimoilaze. Da ih sve ne voli, ne bi ih stvarao tolike. [...] Ne čeznite za drugim svjetovima dok ste u ovome jer su svi svjetovi od jednog jedinog Boga i svi su vam suđeni ${ }^{7}$

- pouka je ove priče. U drugom dijelu romana nestaje Husajn jer je Rabijina muzika koju je slušao bila toliko savršena da se njegova duša povezala „, njezinom svirkom onda kad je ta svirka zbog ljubavi dostigla savršenstvo i odvela dušu u nevidljivi svijet u kojem i sama obitava" ${ }^{\text {“8 }}$. Dakle, neke smrti su se morale dogoditi radi pouke, kako kaže Karahasan.

Drugi dio romana Istočni diwan obiluje apsurdnim umiranjima čije je uzroke teško odgonetnuti. Najprije, porodica siromašnog ribara, obješena je pred trgovačkom džamijom: „Na raznim visinama i na raznim granama, ali svi isto. Mrtvi. Ne zna se ko ni kada. Ni zašto" ${ }^{\text {“9 }}$. Zbog njihovih čistih, bijelih lica istražitelju je jasno da nisu umrli vješanjem i da iza njihove smrti stoji neka velika tajna jer „Zašto bi neko vješao mrtve ljude?" ${ }^{10}$ Slijedi bizarna smrt bogatog trgovca Sufja-

6 „Mukaffa (Abdullah ibn al-Mukaffa, 720-756, približno), arapski pisac perzijskog porijekla iz naselja Džur u provinciji Fars. Do prelaska na islam zvao se Rusbeh i bio zoroastorijanac. [...] Mukaffino djelo se u potonjoj arapskoj književnosti razgranalo čitavim nizom utjecaja: žanr adaba, kojim su obuhvaćeni veliki pisci kakvi su Džahiz, Tauhidi, Hamzani i Hariri, začinje se upravo u Mukaffinom djelu; veoma popularan žanr poučne priče čiji se događaj zbiva među životinjama (zastupljen i u jednom ciklusu Hiljadu i jedne noći) začinje se u njegovom zborniku Kalila i Dimna; mnogi sufije, među kojima Husein al-Halladž nije najmanje značajan, proglašavaju Mukaffu svojim pretkom po tome što se pojmom Božijeg jedinstva, koji korelira sa sufijskim pojmom ljubavi, brisao granice među ljudima i religijama. Mnogi među onima koji su ga izabrali za svog pretka našli su smrt sličnu njegovoj“. M. Memija, Registar imena i pojmova, [u:] Dž. Karahasan, Istočni diwan, Sarajevo 2007, s. 339-340.

${ }^{7}$ Dž. Karahasan, Istočni diwan..., s. 91.

8 Ibidem, s. 248.

${ }^{9}$ Ibidem, s. 126.

${ }^{10}$ Ibidem, s. 135. 
na koji se za večerom naprosto rasprsnuo - „U životu sam vidio svega i svačega, ali ništa ni blizu tako jezivo i odvratno" "11. Nakon toga, rijeka nosi dvadeset i sedam tijela bez ikakvog traga nasilne smrti, pa se al-Razijev unuk rasprsnuo, pa je al-Razi umro tako što je njegova koža postala potpuno zelena... Izvan romanesknog vremena sadašnjeg, u starim neriješenim slučajevima, Gazvan pronalazi da se veliki šejh al-Džunajd rasprsnuo, dok je Omer ibn Osman al-Meki umro potpuno zelen. Svi misteriozno ubijeni ljudi kao i Ibn Tevab (zadavljen u prostorijama princa Hasana), te Abu Said i Abdulah (ubijeni objašnjivom smrću), uz al-Mukaffu iz prvog dijela i roba Behrama iz trećeg dijela romana, imaju funkciju onog miša iz ogledalne umetnute priče. Jasno je da je riječ o neobjašnjivim ubistvima čija je jedina poveznica poznavanje, susret ili sukob sa al-Hallagom, te da su ova ubistva okosnica modela kriminalističke priče koju Karahasanov roman, kao tipičan posmoderni tekst gradi da bi bio urušen. Sve smrti su uvjetovane političkom zavjerom, potrebne kriminalističkoj fabuli, i sve su mjesta kompozicijskih i značenjskih čvorišta. Jednom ispričana priča o smrti mora biti realizirana u svakoj narednoj priči u priči (priča na treću!).

Zašto je važna veza umrlih sa al-Hallagom? U stvarnom svijetu Al Hallag je rođen 244. (857) godine i jedan je od najistaknutijih predstavnika sufizma koji je nakon prvog povratka iz Meke skinuo sufijski ogrtač i otišao na ulicu propovijedati svoje učenje običnim ljudima. Kako bilježi historija, poznavao je tadašnjeg slavnog liječnika i filozofa Razija, bio u dobrim odnosima sa Ganabijem, pa i princom Hasanom, no ipak je protiv njega izdata fetva, nakon čega je više od osam godina proveo u zatvoru da bi zatim bio i pogubljen 309. (922) godine. Njegovo učenje je smetalo i ljudima na vlasti, i pravnicima, i ostalim sufijama, i šiitima i sunitima, iako su svi imali svoje razloge. Jer on „Tvrdi da je krajnji cilj svih bića, a ne samo sufija, sjedinjenje s Bogom, sjedinjenje koje se ostvaruje putem Ljubavi, koja opet iziskuje preobražavajuće božije djelovanje što neko biće vodi do nekog uzvišenog mjesta"12. Središnji i centralni dio romana Istočni diwan nosi naslov Al-Hallag. U pitanju je dnevnik emira straže koji pokušava razriješiti niz neobičnih ubistava u gradu, a koja se po njegovom mišljenju mogu pripisati Iskrenoj braći ${ }^{13} \mathrm{i}$ al-Hallagu. Poznati sufija je odsutni neprijatelj koji se u romanesknom vremenu sadašnjem uopće ne pojavljuje, no njegovo učenje je sveprisutno.

11 Ibidem, s. 148.

12 H. Corbin, Historija islamske filozofije, prev. N. Smailagić i T. Haverić, Sarajevo 1987, s. 177.

13 „Iskrena braća - (Ihwan as-Safa) tajna grupa slobodnih mislilaca osnovana u Basri. Puno ime grupe (Braća čista srca i iskušane vrijednosti, odnosno Pravi prijatelji, vjerni drugovi, ljudi koji zaslužuju pohvalu i sinovi slave) formulirao je, nekoliko stoljeća unaprijed, Abdullah ibn al-Mukaffa u poglavlju „Golubičina ogrlica“ svoje knjige Kalila i Dimna. Svoju filozofiju Braća su izložila u enciklopedijski zamišljenim Raspravama u kojima se obrađuju epistemologija, propedeutika, matematika, logika, prirodna filozofija, psihologija, metafizika, astrologija, mistika... U knjigu je uključena $51(17 \times 3)$ rasprava, s tim da one čine cjelinu s kasnije dodanom Sveobuhvatnom raspravom koja je summa čitave knjige, tako da ih ima $52(5+2$ je 7$)$. Iskrena braća su nastojala stvoriti sintezu grčke filozofije, osobito njezinog pitagorejskog toka, s islamom, što je rezultiralo jednom izrazito ezoteričnom varijantom islama [...]“. M. Memija, Registar..., s. 337. 
U trenutku hapšenja, piše Gazvan, al-Hallag, ,[...] je vikao koliko ga grlo nosi i pozivao ljude da ga ubiju, ubjeđujući ih da je u njegovoj smrti njegov život"“14. Gazvanovo neprekidno protivljenje dualizmu pokazuje odnos državnog islama prema sufijskim pokretima, odnosno, egzoterika prema ezoterizmu, no ipak, na kraju preobražaja roba u Hallaga emir straže više nije siguran u vlastite stavove. Al-Hallag je nestao, no da li je to bio zaista Hallag ili rob ostaje tajna. Jedino sigurno jeste to da su okovi u tvrđavi ostali prazni. Drugim riječima, njegovo učenje živi jer se nakon ovog perioda može govoriti o potpunoj zrelosti tesawufa i brojnih tarikata, a „Hallagov lik ostao je i u tesawufu i u istočnoj poeziji simbol mučeništva u ime tawhida“"15.

U romanu Istočni diwan ukupno se pominje četrdeset i pet nasilnih smrti, jedna prirodna, četvero ljudi je naprosto 3. nestalo - dodamo li tom zbiru i miša iz umetnute priče dobit ćemo broj pedeset i jedan što je poznati broj rasprava Iskrene braće. Na ovaj način roman se kao cjelina povezuje sa učenjem mistika koji su javno propagirali odricanje , ,...] i od ovog svijeta i od onog svijeta u ime boga i ljubavi prema bogu“"16. Po njima, nakon smrti čovjeku nagrada nije raj već neposredna prisutnost Boga.

Mukaffino viđenje smrti (a umro je sto godina prije al-Hallagovog rođenja) nešto je drugačije. Naime, on smatra da ,,[... na ovom svijetu moramo ostati koliko možemo, ma koliko znali da je onaj bolji‘ ${ }^{\text {‘17 }}$, da nam je razum neophodan da bismo dokučili vječnost i to ,[...] kolika je prednost Onoga svijeta nad Ovim““18, te da svi ljudi sigurno idu u smrt i da tu nema mjesta za strah. No, pred odlazak $\mathrm{k}$ namjesniku sa znanjem da će biti osuđen na smrt, Mukaffa prvi put osjeća ljepotu života, onog običnog, i shvata da je istina koju je sve vrijeme tražio bila pred njim: „Ispunjen svijetlom radošću, išao je Mukaffa kroz Basru i osjećao da voli svijet jer ga je taj svijet konačno primio u sebe ${ }^{\text {"19 }}$. Nakon njegove smrti, na svitku koji se sam ispisuje u Rustemovim rukama, između ostalog, piše: ,[...] svoje priče smo pročitali prije nego što su nam se dogodile. Nevidljivi svijet nam je stalno govorio, a mi nismo čuli i nismo znali, ali to je ipak milost, i čudo, i ja se radujem“20. Stotinjak godina kasnije, liječnik Tanabi pojašnjava Gazvanu odnos između duše i tijela uvjeravajući ga da čovjek živi zahvaljujući svetom jedinstvu (trouglu) između duše, unutrašnjeg i vanjskog tijela. U slučaju ubistva, ovaj trougao se nasilno prekida a duša ubijenog se ne osjeća dobro ,[...] ni u nevidljivom svijetu, jer za taj svijet nije dovoljno umorna i ohlađena sokovima unutrašnjeg tijela. Zato ubistvo i jeste grijeh. Takva se duša uglavnom vraća u ovaj svijet kao džin, dobar ili zao, jer ne pripada do kraja ni vidljivome ni nevidljivome

\footnotetext{
${ }^{14}$ Dž. Karahasan, Istočni diwan..., s. 224.

15 N. Filipović, Tesawwuf: islamski misticizam i druge studije, Sarajevo 2011, s. 23.

16 Ibidem, s. 17.

${ }^{17}$ Dž. Karahasan, Istočni diwan..., s. 28.

18 Ibidem, s. 32.

19 Ibidem, s. 98.

${ }^{20}$ Ibidem, s. 114.
} 
svijetu“21. S druge strane, ako se duša dovoljno umori od veze sa unutrašnjim i vanjskim tijelom, dolazi do prirodne smrti, koja je dobra i zahvaljujući kojoj se ona vraća ,[...] svome nevidljivom svijetu, s Božijom voljom i s Njegovim pristankom". 22 I to je uobičajen red kakav odgovara i policajcu i njegovim nadređenim, red u kojemu nema pretjerane čežnje ni na ovom svijetu (jer se duša može sukobiti sa tijelom), ali ni čežnje za onim svijetom (što propagiraju sufije u svojem učenju). Život u državi mora biti uređen i kontroliran, a ljudi su, kako kaže skeptična Rabija, naprosto smrtni: „A kad je neko smrtan, kako ćeš znati je li umro od sebe ili ga je neko ubio? Pa i ako znaš, ni tebi ni njemu nije ništa bolje“ ${ }^{\text {“23. }}$.

Karahasanov drugi roman, Šahrijarov prsten, ostvaren je kao trostruki niz priče u priči kroz različita vremena i prostore, te putem različitih naratorskih instanci. Prvi okvir tematizira neobičnu ljubav Azre i Faruka u predratnom Sarajevu, te Azrino čitanje Farukivih rukopisa u ratnom Sarajevu. Odsutnog autora reispisuje čitateljica njegovog teksta o pjesniku Figaniju iz vremena osmanske Turske. U uvodnim Farukvim esejima dominira motiv smrti, a to dalje znači da je kompletan roman premrežen naratorovim promišljanjima o smrti kao i njegovim doživljajem umiranja bliskih ljudi. Prvi događaj u fabularnom vremenu sadašnjem jeste sahrana Farukovog tetka, razgovor sa Azrom i razmišljanje o smrti. Prva rečenica, nakon eseja o modernom namještaju, glasi: „Snijeg je padao u teškim vlažnim krpama šireći svijetom mir i tišinu, šireći lijepu bijelu smrt“24. Faruk odlazi sa sahrane prije njenog završetka uz osjećaj, ,[...] krivnje što smrt svojih dragih ne doživljavam dovoljno duboko“ ${ }^{\prime 25}$, uvjeren da je tetku sada dobro i da ,[...] njegova duša sada sigurno plovi prema nekoj južnoj padini prekrivenoj plamenim cvjetovima tikve“ ${ }^{26}$. Ravnodušnost spram umiranja Faruk opravdava sjećanjima iz djetinjstva. Sa smrtima se sreo veoma rano, te u njegovom životnom iskustvu smrt ne predstavlja ništa veliko i bitno - kaže onaj čiji su život odredila umiranja voljenih ljudi. Njegov veliki brat Hajrudin je izvršio samoubistvo, a mali dječak Faruk je vjerovao da je stariji brat to učinio samo zato da bi se on osjećao važnim. „Problemi su se pojavili kasnije, kad se pokazalo da se Hajrudin ne vraća i ne

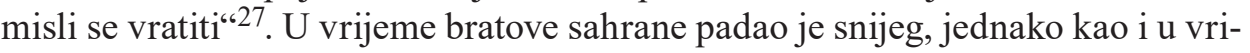
jeme sahrane najboljeg dječakovog prijatelja, starog Bahtijara, kojeg je pronašao mrtvog u kući, i pred čijom je pogrebnom povorkom nosio natpis sa imenom. „Tako je sahranio Bahtijara po snijegu koji je sipao kao da je došlo vrijeme da se zatrpa svijet, po istom onakvom, možda po istome onom snijegu koji je sipao prije godinu dana, kad je otišao otac" ${ }^{\text {"28. }}$. Faruk priča Azri o sahranama i svom osjećaju

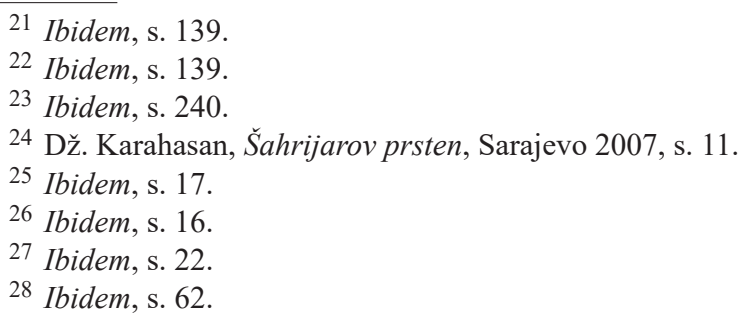


krivnje razvijenom u djetinjstvu dok je još mislio da dragi ljudi umiru namjerno, da bi on bio u centru pažnje. I sve to u vrijeme svadbe jer vjeruje da su svadba i smrt slični rituali: ,[...] jedini događaj koji ga pred svjedocima prevede u novo,

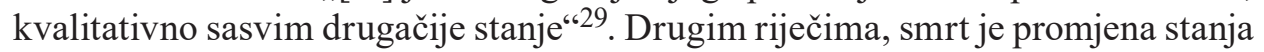
kroz trenutak sjedinjenja. Zato je smrt uvijek lijepa i bijela: i na tetkovoj sahrani, i u sjećanju na sahrane iz djetinjstva, i onda kad se rodio ,[...] pod snijegom, pod pravom kupolom pahulja iz kojih je zračila tišina puna lijepe bijele smrti“ ${ }^{\star 30}$. Tako snijeg zbog svoje bjeline i strukture postaje temeljna metafora smrti:

S onim svijetom ga vezuju struktura pahulje, hladnoća, ravnodušnost i tišina, a s ovim svijetom oku vidljiva strukturacija, nestalnost, mekušnost i glupo doslovna prisutnost u ovome neposredno datom. Ta se granična pozicija snijega sasvim jasno vidi u njegovoj bijeloj boji koja nije od ovog svijeta, koju u priručnicima o simbolici boja nazivaju odsutnosti i ponekad bojom smrti jer je bijelo odsutnost boje, a pri tom je, bez obzura na priručnike za nježne duše, tako tupo i doslovno prisutna, tako neporecivo vidljiva da je snijeg sasvim neproziran. Snijeg je, dakle, grešni iskorak onog svijeta prema ovome ili isto toliko grešan pokušaj ovog svijeta da se dozivanjem smrti pokrene prema onome.

Snijeg je jedina materija koja svojim kretanjem proizvodi tišinu. [...]

On uzvišeno čist prekriva sve, šireći svijetom tišinu i ravnodučnost koje zrače iz savršene kristalne strukture njegovih pahulja. Kao lijepa bijela smrt ${ }^{31}$.

Snijeg objedinjuje sve uspomene na umiranja, te asocijativno uvlači misao o rođenju i vjenčanju. Dobri ljudi, veruje Faruk, umiru dobro i prelaze na drugu stranu u sjedinjenju sa bjelinom. Smrt je dobra. Farukova posljednja misao je: „Bože, da je otići! Samo da je ne ostati nakon svoga pravog časa! To je zapravo jedino važno! ‘32

Rukopis „Godine učenja šejha Figanija“, kao drugi narativni prsten, vodi nas u šesnaestovjekovni Istanbul i Figanijeva promišljanja o ovome i onome svijetu, dok nas kao drugi fabularni krug zavodi postmodernistički napetom političkom zavjerom i krimi-pričom koja donosi niz nasilnih umiranja. Najprije će Figani od učitelja Idriza saznati ko je bio pobunjenik Bedredin ${ }^{33}$ (za kojeg se sada predstavlja njegov novi učitelj Demir), te kako je stradao. Njegova pobuna je ugušena, on obješen, a njegovi saradnici svirepo kažnjeni - ludi Mustafa je razapet na dasku, prikovanih ruku i nogu u obliku križa, a onda na devi proveden kroz grad i kamenovan. ,[...] znam za toliko sličnih sudbina da pomišljam kako postoji sorta stvorenja kojima je u naravi ili sudbini (ako to nije isto) da budu na nekom živinčetu provedeni kroz grad, izloženi smijehu, poruzi, pljuvanju i udarcima ljudi, da bi na kraju tog pohoda bili umoreni ${ }^{634}$. I upravo će ovakva, karnevalizirana ali ne

29 Ibidem, s. 63.

30 Ibidem, s. 34.

31 Ibidem, s. 33.

32 Ibidem, s. 354.

33 Šejh Bedredin je autor filozofsko-mističkog djela Varidat. Ustanak iz 1416. godine koji je šejh pokrenuo sa svojim učenicima protiv feudalne vlasti imao je izraziti socijalni karakter.

${ }^{34}$ Dž. Karahasan, Šahrijarov prsten..., s. 166. 
karnevalska već istinska smrt biti ponavljajući motiv romana Šahrijarov prsten. „Kao po nekom redu i rasporedu“ i pjesnik Figani će umrijeti na isti način, jer u svojoj fabularnoj liniji on je izabran da bude ludi Mustafa - osuđen je na sramni prolazak kroz grad, vezan na magarcu naopačke i kamenovan do smrti.

Razlozi Figanijevog smaknuća političke su prirode, a inscenirani povod je njegov rad na rukopisu „Povratak u Ereh“, priči koja je ujedno treći narativni nivo romana. Protagonista središnje priče romana je džin Bell koji je došao među ljude sa odlukom da postane čovjek da bi mogao voljeti i da bi mogao umrijeti. Svojoj dragoj ženi Belitsilim on govori o besmislu besmrtnosti:

- Velika je stvar: umrijeti. Možeš se ti smijati kad znaš da ćeš umrijeti, tada se možeš i radovati i smijati.

- Nisam znala da je to tako dobro.

- Ogromno, najveće. Daje oblik.

- Kakav oblik?

- Razumljiv. Uređen prema unutrašnjem, prema razlogu i prema prirodi onoga što je oblikovano. Bilo bi vam strašno da nije smrti. Ili ne bi jer ne biste bili ljudi. Rijeci nije svejedno koliko je između njezinog izvora i ušća, ali joj to nije važno koliko to da ima izvor, tok i ušće. Bez ušća ona ne bi bila rijeka ili bi tekla nikamo a nikamo se ne može teći. ${ }^{35}$

Postoje dobri i loši džini, i oni treći kojima pripada Bell. Oni su dvostruke prirode, ne žudnja za nečim nego žudnja po sebi. Oni su sve, cjelina, i vatra i svjetlost. Stoga on odlučuje postati čovjek: da bi bio onaj koji žudi, a ne žudnja sama, da bi se oslobodio ravnodušnosti: „Ja ću se odreći svoje besmrtnosti radi žudnje za tobom, ja ću izgubiti besmrtnost da bih te žudio, ja ću se smrti prepu-

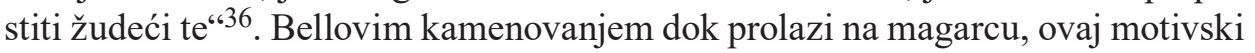
krug romana biva konačno zaokružen i zatvoren, a besmrtnik mrtav: „Možeš li zamisliti kako je strašno biti besmrtan i ravnodušan? Možda to mora biti jedno s drugim, možda su to dva oblika istog imena, ali se nama baš u tom spoju otkriva užas $[\ldots]^{\text {‘37 }}$. Voljena žena ostaje sa Bellovim djetetom u sebi i sa čežnjom ka ,[... [ raskriljenim vratima i svijetlim odajama kroz koje će proći da se sjedini sa sjajem“338. A kako je ova umetnuta priča tek priča-ogledalo o ljubavi i čežnji, o sjedinjenju i stapanju u jedno, tako okvirna priča o Azri i Faruku završava Azrinim reispisivanjem Farukovih rukopisa u kojima pronalazi i njega, i njihovu ljubav u jedinstvu autora, teksta i čitateljice. Sufijsko sjedinjenje sa Jednim na kraju ovog romana Karahasan prenosi u jezik i putem velikog civilizacijskog citata ispisuje kao sjedinjenje u tekstu i njegovim smislovima. Azrine posljednje riječi su: „Čekam te. Znam da ćeš doći jer smo, nažalost, zauvijek oslobođeni smrti. U onome što nam je preostalo, u onome što nam je suđeno, moramo se opet sresti. Daj Bože da saznamo zašto je to dobro“39.

\footnotetext{
35 Ibidem, s. 220.

36 Ibidem, s. 229.

37 Ibidem, s. 227.

38 Ibidem, s. 241.

39 Ibidem, s. 356.
} 
Romani Istočni diwan i Šahrijarov prsten Dževada Karahasana kao klasični romani postmodernizma ispisani su kroz poigravanje sa različitim žanrovskim i narativnim obrascima, uvlačenjem $u$ fabulu historijskih ličnosti i događaja, te kroz veliki citatni i intertekstualni dijalog sa kulturom i religijom islama. Na fabularnom nivou romana smrt se pojavljuje kao temelj zapleta u nizu političkih ubistava, dok je specifična smrt (miš u rupi ili odsijecanje ruku i nogu u Istočnom diwanu, te prolazak kroz grad na nekoj životinji i kamenovanje u Šahrijarovom prstenu) kao ponavljajući motiv jedno od kompozicijskih čvorišta romanesknih struktura. S druge strane, kroz analizirane Karahasanove romane moguće je pratiti odnos prema smrti u različitim historijskim periodima: od predislamskog doba (Dolazak u Ereh), preko osmog vijeka (al-Mukaffa), devetog na deseti (Al-Hallag), jedanaestog (at-Tawhidi) i šesnaestog (Figani), pa do devedesetih godina dvadesetog vijeka (Faruk i Azra). Kako god se u kršćanstvu vodila borba između gnoze i historizirane kršćanske religije sa posredničkom ulogom crkve, tako su se u islamu sukobljavali ezoterici sa egzotericima koji smatraju da su vjerovanje i poštivanje normi ponašanja važniji od mišljenja. Helenizirana struja islamske filozofije, produbljena u ezoteričku misaonost i spiritualnu religiju dovela je do razvoja islamskog misticizma. Misao o putu vraćanja početnom izvoru, a koji se prolazi unutarnjom spoznajom i žudnjom, temeljna je odrednica kako određenih likova tako Karahasanovih romana u cjelini. Lijepa bijela smrt je sjedinjenje s Jednim.

\section{Bibliografija}

Corbin H., Historija islamske filozofije I-II, prev. N. Smailagić i T. Haverić, Sarajevo 1987.

Denić-Grabić A., Otvorena knjiga: elementi postmodernog diskursa u romanima Dževada

Karahasana Istočni diwan i Šahrijarov prsten, Zagreb-Sarajevo 2005.

Filipović N., Tesawwuf: islamski misticizam i druge studije, Sarajevo 2011.

Karahasan Dž., Istočni diwan, Sarajevo 2007.

Karahasan Dž., Šahrijarov prsten, Sarajevo 2007.

Kos-Lajtman A., Drugo lice smrti: tretman i uloga teme smrti u prozi Dževada Karahasana, „Sarajevske sveske“ 2016, br. 49-50.

\section{The motif of death in the novels of Dževad Karahasan}

\section{Summary}

Dževad Karahasan's novels The Eastern Diwan and Shahriar's Ring, being the classic examples of postmodernism, feature various forms of play with genres and narrative patterns, the presence of historical persons and events, and significant intertextual dialogue, namely, quotations, with cultural and other elements of Islam. The motif of death is analyzed within the context of the plot, which is founded on this theme, as it consists of several political assassinations; whereas the idea of death as a repetitive motif is one of the compositional anchors of the novelistic structure. On the other hand, through the analysis of Karahasan's novels it is possible to follow the 
attitude towards death in different periods of development of Islamic philosophy. In particular, the Hellenized strain of Islamic philosophy, rooted in esoteric thinking and spiritual religion, has led to the development of Islamic mysticism. The idea of the path of returning to the original source, which is transmitted through inner cognition and craving, is found to be the basic determinant of certain characters in the novel, as well as of the novel as a whole.

Keywords: death, sufism, The Eastern Diwan, Shariar's Ring

\section{Motyw śmierci w powieściach Dževada Karahasana}

\section{Streszczenie}

Utwory autorstwa Dževada Karahasana Istočni diwan i Šahrijarov prsten, jako klasyczne powieści postmodernistyczne, cechuje gra prowadzona z różnorodnymi formami gatunkowymi i wzorcami narracyjnymi, sięgnięcie po postaci i wydarzenia historyczne oraz — za sprawą licznych cytatów - dialog prowadzony z kulturą i pozostałymi elementami islamu. Analizie poddana zostanie śmierć, uwidoczniająca się w warstwie fabularnej powieści i będąca podstawą spisku w serii zabójstw politycznych, jako motyw powtarzający się — jeśli jest specyficzna — oraz jako jeden z węzłów kompozycyjnych struktur powieściowych. Jednocześnie podczas analizy powieści autorstwa Karahasana można śledzić stosunek wobec śmierci w różnych okresach rozwoju filozofii islamu. Mianowicie, zhellenizowany strumień filozofi muzułmańskiej, zanużony w myśli ezoterycznej i spirytualizmie religijnym doprowadził do rozwoju mistycyzmu muzułmańskiego. Idea powrotu do źródła, który prowadzi przez wewnętrzne poznanie i pragnienie, okazuje się podstawowym wyznacznikiem zarówno niektórych postaci, jak i powieści jako całości.

Słowa kluczowe: śmierć, Istočni diwan, Šahrijarov prsten, sufizm, Dževad Karahasan 